\title{
REFLECTING ON FUNCTIONAL DISCOURSE GRAMMAR AS I SELF-ISOLATE
}

\author{
J. Lachlan MACKENZIE iD $\boldsymbol{\Delta}$ \\ VU Amsterdam, De Boelelaan 1105, 1081 HV Amsterdam, Países Baixos
}

\section{ABSTRACT}

These reflections begin by sketching the origins of Functional Discourse Grammar (FDG) in Simon Dik's Functional Grammar and then by setting out some of the major principles of FDG. The Dik-inspired approach emphasized here puts a focus on an interpretation of the theory that gives a prominent place to dialogue and the speakers' communicative strategies. The discussion commences with speakers' discursive strategies and then moves on to their lexical strategies. Finally, drawing on corpus data, attention is devoted to the verb self-isolate in English, a new verb that was created in the early days of the coronavirus crisis.

Open access

EDITORS

- Miguel Oliveira, Jr. (UFAL)

- René Almeida (UFS)

REVIEWERS

- Daniel Velasco (UNIOVI)

- Roberto Camacho (UNESP)

DATES

-Received: 03/26/2021

- Accepted: 04/20/2021

-Published: 06/25/2021

HOW TO CITE

MACKENZIE, J. Lachlan (2021).

Reflecting on Functional Discourse

Grammar as I Self-Isolate. Cadernos

de Linguística, v. 2, n. 1, e361.

\section{RESUMO}

As origens da Gramática Discursivo-Funcional (GDF) encontram-se na Gramática Funcional de Simon Dik. Depois de explicitar alguns dos principais princípios da GDF, este ensaio salienta uma abordagem pósdikiana que dá um lugar de destaque ao diálogo e às estratégias comunicativas dos falantes. O núcleo das reflexões debruça-se sobre as estratégias discursivas dos falantes e, em seguida, passa para as estratégias lexicais. Finalmente, com base em dados de corpus, dedicase atenção ao verbo self-isolate em inglês, um novo verbo que foi criado nos primeiros dias da crise do coronavírus. 
KEYWORDS

Functional Discourse Grammar; Dialogue; Communicative Strategies; Neologisms; Language and COVID-19.

\section{PALAVRAS-CHAVE}

Gramática Discursivo-Funcional; Diálogo; Estratégias Comunicativas; Neologismos; Linguagem e a COVID-19. 


\section{INTRODUCTION}

I wish to begin by thanking ABRALIN and its President Miguel Oliveira Jr. for honoring me with an invitation to contribute a talk and now an article to the fantastic ABRALIN ao Vivo initiative. This series of conferences and round tables - as well as the videos and articles that have arisen in their wake - is a perfect answer to the challenges of the pandemic which, in addition to many other horrible effects, has severely perturbed university teaching and research. The series is also a response to the anti-intellectualism that characterizes current times and is nowhere in the world more visible and more tangible than in Brazil. I see this contribution of mine as a continuation of the many opportunities that have been granted me in recent years by Brazilian colleges and institutions to lecture and teach courses on Functional Discourse Grammar (FDG).

It is a remarkable fact that FDG is practiced at numerous Brazilian universities, and I would like to take this opportunity to greet and pay my respects to my colleagues at the São Paulo State University (UNESP) of São José do Rio Preto, the Federal University of Mato Grosso do Sul, the Federal University of São Carlos, the Federal University of Goiás, the Federal University of Ceará, the Federal University of Rio Grande do Sul, the Federal University of Rio de Janeiro, the Federal University of Rio de Janeiro, and the State University of Maringá, in addition to the colleagues that invited me to teach at the Mackenzie Presbyterian University and to lecture at the UNESP campus in Araraquara, and last but not least, at the University of São Paulo.

In these reflections, composed during a period of self-isolation in Lisbon, I want to begin by sketching the origins of FDG in Simon Dik's Functional Grammar (DIK, 1997), briefly setting out some of the principles of FDG (HENGEVELD and MACKENZIE, 2008), and then focusing on an interpretation of FDG that gives a prominent place to dialogue. I intend to enter into speakers' discursive strategies and then their lexical strategies, and finally dedicate a few words to the verb self-isolate in English, a new verb that was created in the early days of the coronavirus crisis.

Functional Discourse Grammar emerged in the early years of this century as a successor theory to Functional Grammar as developed by Simon C. Dik, one of the key figures of linguistic functionalism. Dik's Functional Grammar (DIK, 1978; 1980; 1989; 1997) was conceived as a grammar of the clause. We must bear in mind that his model emerged in the seventies and eighties of last century, in the context of the dominance of Generative Grammar (CHOMSKY, 1981), the Case Grammar of Fillmore (1968), the Relational Grammar of Perlmutter and Postal (1983), and many other models of the clause. At that time Dik was working with very much the same assumptions: the focus on clauses was also apparent in his work on the computational implementation of his theory (DIK, 1992). In the nineties Simon fell ill and passed away in 1995. In the last chapter of his final, posthumously published book 
(DIK, 1997), he outlined what he called a "grammar of discourse", which he saw as an extension of his previous work on the clause. This chapter was certainly a response to a growing wave of interest on the part of Functional Grammar practitioners in general in the extent to which the theory could be made to cover not only the impact of discourse on syntactic structure but also discourse itself. After all, most of these practitioners were teachers and researchers in foreign language departments (as I was, too, in an English language department): our daily work confronted us with the interface between grammar and textuality. In addition, there was a strong presence in the group of scholars of classical languages whose corpora of Latin and Greek texts were by definition textual and increasingly consultable by computer. After Dik's death, there was a lively debate in the last years of the twentieth century on how to incorporate elements of pragmatics and even discourse analysis into Functional Grammar (MACKENZIE, 2016).

The resolution of this debate came in the year 2000. At a conference in Madrid, Kees Hengeveld, Dik's successor as Professor of Theoretical Linguistics in Amsterdam and his most distinguished disciple, proposed a new model that synthesized the points of conflict and corrected several limitations of the existing model (published as HENGEVELD, 2004). He suggested that the new model should be called Functional Discourse Grammar, inserting the word Discourse between Functional and Grammar, and the name was accepted. FDG had, and still has, as its central proposal the idea that the organization of grammar into layers characteristic of Dik's theory should be applied not only to the semantic aspects already covered by Functional Grammar but also to various discourse-related aspects, specifically the illocution and other grammatical reflexes of verbal interaction.

This was achieved by distinguishing two separate levels within the grammar, each with its own internal layering: the Representational Level, which resembled the underlying representations in Dik's grammar, and the Interpersonal Level, which encompassed the impact of discourse on grammatical organization. In addition, Hengeveld outlined two other levels of analysis, now called the Morphosyntactic and Phonological Levels, both also divided into hierarchically organized layers, in the same way as the Interpersonal and Representational Levels. This was how FDG emerged, and in the last twenty years it has slowly but effectively replaced Dik's model.

The central text of the FDG is the book Functional Discourse Grammar. A TypologicallyBased Theory of Language Structure (HENGEVELD and MACKENZIE, 2008); for a more introductory book, see A Functional Discourse Grammar for English (KEIZER, 2015). See the extended bibliography for a succession of books and special issues of academic journals dedicated to FDG since 2004.

What, then, are the major characteristics of FDG? The most prominent is that, while Dik's Functional Grammar, like the vast majority of grammatical models, was a grammar of the clause, FDG is a grammar of Discourse Act. Human beings who engage in verbal 
interaction are expending energy in an attempt to influence each other; this activity is divided into Discourse Acts. In syntactic terms, these Acts can take the outward form of a clause, but also one or more phrases or a simple word or indeed units that cover more than one clause. These Discourse Acts $\left(A_{1 \ldots n}\right)$ are the central elements of the Interpersonal Level and are grouped into Moves $\left(M_{1 . . n}\right)$ :

(1) $\quad\left(M_{1}:\left[\left(A_{1}\right) \ldots\left(A_{n}\right)\right]\left(M_{1}\right)\right)$

There has been a lot of interest in the internal organization of these Moves, that is, in the relations between Discourse Acts, in terms of both equipollence (similar to parataxis) and dependency (similar to hypotaxis). Work on such external relations of Discourse Acts has been located at the interface between grammar and discourse analysis. But FDG also pays attention to the internal structure of Acts. While the Move represents a higher layer than that of Discourse Acts (cf. (1)), there are also lower layers. In the case of the Discourse Act, there are usually four units: the Illocution $\left(F_{1}\right)$, the speaker $\left(P_{1}\right)$, the addressee $\left(P_{2}\right)$, and the Communicated Content $\left(\mathrm{C}_{1}\right)$.

The analysis at the Interpersonal Level of an utterance such as Portuguese Cansada? ('Tired?') will run as follows. The Act consists of four parts in an equipollence relation, signaled by the square brackets: an Interrogative Illocution, a Speaker, a female Addressee (the femaleness being indicated by the lowercase operator f), and a Communicated Content, which in this case contains, at a lower layer, a single Subact of Ascription ( $\left.T_{1}\right)$ :

(2) $\left(A_{1}:\left[\left(F_{1}: \operatorname{INTER}\left(F_{1}\right)\right)\left(P_{I}\right)_{S}\left(f P_{J}\right)_{A}\left(C_{l}:\left(T_{1}\right)\left(C_{I}\right)\right)\right]\left(A_{1}\right)\right)$

Compare the analysis of Obrigada! ('Thank you!') in (3):

(3) $\left(A_{\mathrm{I}}\right.$ : $\left[\left(F_{\mathrm{I}}\right.\right.$ : $\left(D_{\mathrm{I}}\right.$ : obrigad-Inti $\left.\left.\left.\left.\left(D_{\mathrm{I}}\right)\right)\left(F_{\mathrm{I}}\right)\right)\left(f \mathrm{P}_{\mathrm{I}}\right)_{\mathrm{S}}\left(\mathrm{P}_{\mathrm{J}}\right)_{\mathrm{A}}\right]\left(\mathrm{A}_{\mathrm{I}}\right)\right)$

Here we see a Discourse Act with only three parts, with no Communicated Content, but with a female speaker, an addressee, and instead of an abstract illocution like INTER(rogative), a lexical illocution. (3) contains the layer $\left(D_{1}\right)$ for lexical Deeds, as proposed by Giomi (2021); this added layer helps us to understand how we can add modifiers to expand these illocutions, for example in infinitamente obrigada 'lit. infinitely obliged, thank you so much'. The analysis in (3) shows that to thank is not to communicate a State of Affairs (the Act has no Communicated Content) but to perform an interactive act.

For a more complete description of these two examples, we would need other levels than the Interpersonal Level: the Representational Level for the ideational element cansad, the Morphosyntactic Level for the attachment of the suffix - $a$, and the Phonological Level 
for the prosodic contours. But this is not the time to go into technical details; all necessary information can be found in Hengeveld and Mackenzie (2008). Rather, let us focus on some considerations that have played a role in the most recent work in FDG, including my own work. Within the group of researchers in FDG there has been a debate between those who favor a view of grammar as a tool used by the individual speaker and others who insist more on a dialogical dimension. The former view was articulated in Hengeveld and Mackenzie (2008, p. 1-2), where it is stated that a model of grammar will be more effective the more its organization resembles linguistic processing in the individual. This view has favored an interpretation of the FDG architecture (for which see Figure 1) as a succession of operations: the sequence starts in the Conceptual Component with pre-linguistic cognitive activity and the emergence of the speaker's communicative intention; it continues in the Grammatical Component with the two formulation operations (which generate the Interpersonal and Representational Levels. Then there are the two codifying operations, which generate the Morphosyntactic and Phonological Levels. All four operations are impacted by the Contextual Component; and the sequence ends with the phonetic, graphological or gestural articulation in the Output Component.

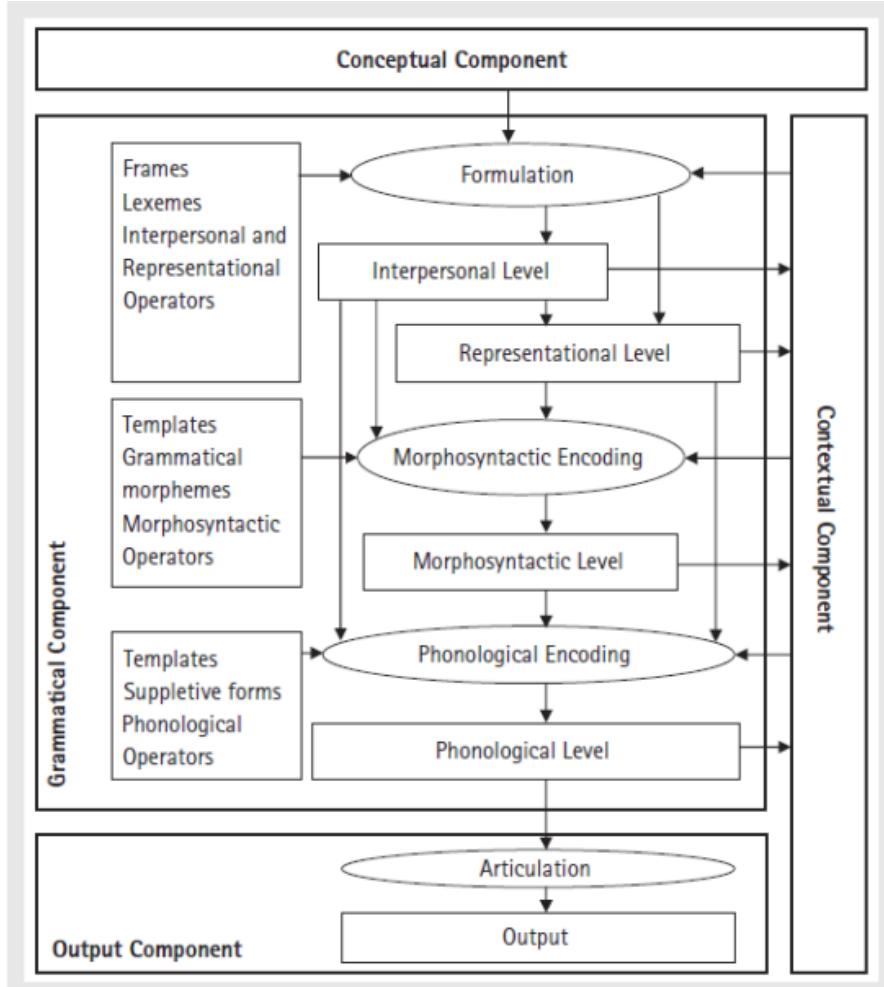

Figure 1. The architecture of Functional Discourse Grammar. 
The second view, the dialogic one, brings back into play the approach advocated by Simon Dik's Functional Grammar, who defended the model represented in Figure 2 (DIK, 1997, Part 1, p. 8).

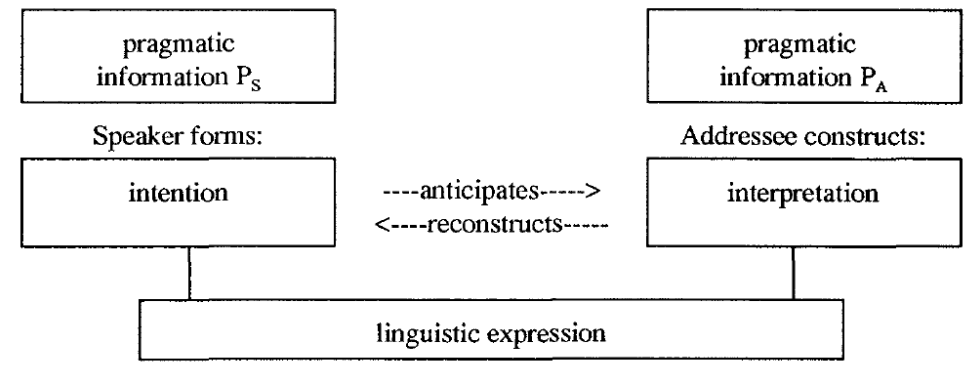

Figure 2. Dik's model of verbal interaction.

Figure 2 represents the speaker and the addressee at some point in a dialogue. Both share a code in the sense that both have the ability to use a shared language actively and passively, as well as sharing their surroundings, the communicative situation in which they find themselves. But they do not share the individual stores of what Dik called their 'pragmatic information'; these stores are entirely personal and encompass the totality of knowledge, beliefs, prejudices, feelings, etc. which together constitute the mind of a participant in a dialogue at a given moment. Seen from this perspective, linguistic communication is equivalent to an attempt on the part of the interlocutors to bridge the gap between their minds by exploiting their shared linguistic competence and their common awareness of the surroundings of their interaction. Then, based on a certain intention, the speaker performs a Discourse Act, and formulates and encodes it in a linguistic expression in such a way that the resulting statement has a reasonable chance of effecting the desired change in the addressee's pragmatic information. The addressee, in turn, when decoding the statement, tries to interpret what they have heard, reconstructing the presumed communicative intention of the speaker. The speaker knows this and anticipates that the addressee will reconstruct their intention.

All of this means that the formulation adopted by the speaker when carrying out a Discourse Act makes a contribution to its interpretation, but does not dictate it. The speaker's words are almost never a complete verbalization of their communicative intention, especially because of additional motivations that go beyond the mere transmission of knowledge, such as the desire to respect the rules of politeness. In the same way, the information decoded by the addressee is only part of the meaning they will take away from the utterance: the total meaning is the addressee's interpretation, which is based on several abductive inferences; this interpretation, for example, often contains an assessment of the speaker. Thus we can conclude that the Discourse Act is 
underdetermined, in the sense that the content of the Act itself represents much less than its total impact; but the Act is obviously also an essential lever for having that impact on the addressee. The view that derives from this dialogical perspective is one of grammar as an instrument, as an intricate, sophisticated tool, used by language users to cast a bridge, sometimes a rather shaky bridge, between the different individuals involved. All of this leads to the conclusion that the two representations of meaning that characterize the FDG analysis of a Discourse Act, the pragmatic meaning at the Interpersonal Level and the semantic meaning at the Representational Level, do not replicate the speaker's conceptualization, nor even the communicative intention his. Instead, the speaker creates the two representations as elements of a 'strategic campaign', so to speak, which aims to have the desired effect on the addressee. For this reason, a Referential Subact $\left(R_{1}\right)$ as part of a Communicated Content $\left(C_{1}\right)$ is never inherently Topic but can be treated as such if that fits into the speaker's communicative strategy; likewise, the desire to make a request never inherently leads to an Interrogative Illocution, but within the framework of a pragmatic strategy of indirectness this is a possible (and indeed generally highly entrenched) option.

This strategic approach was further developed and applied by Hannay and Kroon (2005). After a detailed demonstration of the fact that a Discourse Act, as we have already mentioned, does not have to correspond to a syntactic clause, they maintain that the 'chunking' of ideation into Discourse Acts depends on the speaker's strategic planning (HANNAY and KROON, 2005, p. 104). They agree with the consensus that the most reliable evidence of Discourse Act status comes from prosodic clues. They compare the three examples (4a), (4b) and (4c):

(4) (a) He waited, for ages.

(b) He waited. For ages.

(c) He waited for ages.

All three examples convey the information that he has waited 'for a very long time, obviously with the figure of speech of hyperbole strategically employed by the speaker, setting an easy puzzle which the addressee will solve without problems in the inferential process of interpretation. But the difference between the three examples, informally represented in the punctuation, also depends on the strategy adopted by the speaker: in (4c) the speaker formulates a single Discourse Act with a Focus on ages and lets the words speak for themselves; in (4a), however, we see two Discourse Acts, one dependent on the other, each with its own Focus, respectively waited and ages; and in (4b) there are two equipollent Discourse Acts within a Move with a terminal break after the first. It is evident that the addressee will be influenced in their interpretation by the strategy adopted by the speaker, for example when estimating the degree of impatience and irritation of the man. 
Let us now move on to lexical strategies, approached from the point of view of FDG, appealing to some more recent work on the lexicon (HENGEVELD and MACKENZIE, 2016). A crucial concept is that of the 'frame'. The repertoire of frames (the 'frameset') available in a given language is part of the speaker's competence, captured in FDG in the so-called 'primitives', shown as rectangles on the left side of the Grammatical Component in Figure 1. For example, in Portuguese there are frames for configurational properties of zero valence (like chove- 'rain'), monovalence (like brilha- 'shine'), bivalence (like le- 'read') and trivalence (like $d a$ - 'give'), where valence is the number of arguments attributed by the speaker to a predicate.

$\begin{array}{llll}\text { (5) a. chove-v } & > & \left(f_{1}: \vee\left(f_{1}\right)\right) \\ \text { b. brilha-v } & > & \left(f_{1}:\left[\left(f_{2}: \vee\left(f_{2}\right)\right)\left(x_{1}\right) \cup\right]\left(f_{1}\right)\right) \\ \text { c. le-v } & > & \left(f_{1}:\left[\left(f_{2}: \vee\left(f_{2}\right)\right)\left(x_{1}\right)_{A}\left(x_{2}\right) \cup\right]\left(f_{1}\right)\right) \\ \text { d. da-v } & > & \left(f_{1}:\left[\left(f_{2}: \vee\left(f_{2}\right)\right)\left(x_{1}\right)_{A}\left(x_{2}\right) \cup\left(x_{3}\right) L\right]\left(f_{1}\right)\right)\end{array}$

The lozenge indicates the location of the lexeme, which has its own variable $\left(\mathrm{f}_{2}\right) ;\left(\mathrm{x}_{1} \ldots \mathrm{n}\right)$ here indicate arguments, and the subscripts $\{A, U, L\}$ stand for the semantic functions $\{$ Actor, Undergoer, Locative\}. The Configurational Property (here shown as $f_{1}$ ) is a layer of the Representational Level and functions as the head of the representation of the so-called State-of-Affairs, the next higher layer. There are also other frames in the model, but let us focus here on the most accessible frames, those of quantitative valence within the Configurational Property exemplified in (5). The key point is that the choice of the frame is again a strategic action on the part of the speaker.

The approach depends on the idea that determining which frame will be applied precedes the choice of the lexical item that will occupy it. This procedure is inspired by the literature on speech production, for example by Konopka and Brown-Schmidt (2014). When developing the intention of describing a particular situation, in a first step, speakers start by delineating its global configuration (Is it a state or an event? How many participants are there? What is already known, what is new?); we know this on the basis of eye-tracking studies. Only in the second step will speakers look for lexical items capable of denoting the participants present. In FDG this is modeled by first determining which frame is appropriate and thereafter attributing lexemes to the chosen frame. In this second step, several factors come into play, such as the speaker's intentions, the discourse context, the nature of the interaction (for example in terms of politeness), but also the impact of the entrenchment of the various lexical options as well as the influence of priming. García Velasco (2007) refers in this context to the "lexical competence" of the speaker, defined as the ability to use words based on a set of mostly unconscious beliefs rooted in lifelong experience of hearing and pronouncing those words. 
At this point, I would like to refer to my own experience of learning and adopting the verb self-isolate in English. In the epidemiological crisis, citizens were encouraged or even forced in an initial phase to isolate themselves from possible contagion by staying at home and/or by respecting social distance. At the time of preparing this material for my Abralin ao Vivo talk, I was still limiting my physical contacts with other human beings to a minimum, hence the title of this article. I very well remember the first time I heard the verb self-isolate on British television. The presenter read the word from her teleprompter, the equipment attached to the cameras that displays the text for her to read, and she hesitated, obviously surprised by the word self-isolate, and then felt the need to explain the verb by using the reflexive construction: "That means isolate ourselves, I suppose". The incident reminded me of my own research in the framework of the FDG, published as Mackenzie (2018), into English verbs prefixed with self-, such as self-publish, self-harm, self-regulate, etc. The prefixation of self- is long-standing in the language and dates back to at least the 16th century; in Shakespeare's work, for example, there are 45 words ('types') with this prefix with 59 occurrences ('tokens') in total. But none of these is a verb.

The prefixing of self- to verbs, according to Google Ngram Viewer (https://books.google.com/ngrams), only started centuries later, around 1970, with the first verb being self-destruct, which still leads the field, cf. Figure 3.

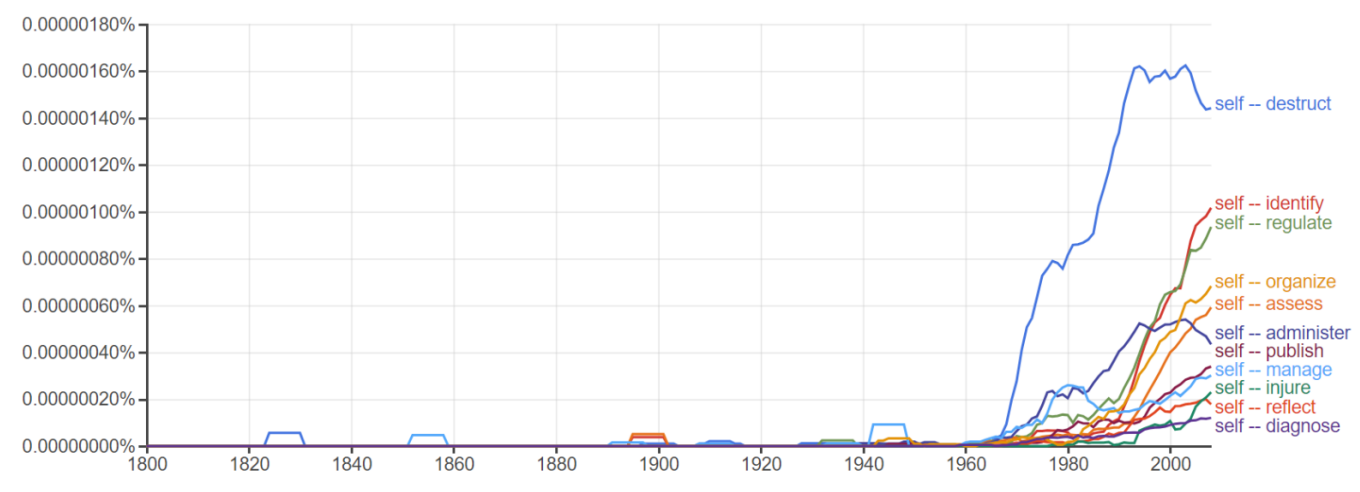

Figure 3. Self-prefixed verbs in Google Ngram Viewer.

The word was possibly coined in science fiction films: spaceships 'self-destruct' in those films for fear of falling into the wrong hands, and then the word self-destructspread across society in general. This relatively new lexical strategy, compressing a situation with two identical participants into a monovalent frame by means of the prefix self-, is a good example of what García Velasco (2016) has called the 'flexible lexicon'. Confronted by an unknown word like self-isolate, the addressee is usually able to interpret the speaker's intention by invoking another lexeme that displays some analogy with the new item, in this case the lexeme self-isolation, which had already existed in the lexicon of many English 
speakers. With the entry of the verb self-isolate into the English lexicon, it can be said that the lexical family \{self-isolation, self-isolating, self-isolator, etc.\} acquired a new member. In addition, as the number of verbs with the prefix self-increased in the English lexicon, so more and more exemplars became available, and these came to form, in the happy expression proposed by Haspelmath and Sims (2010, p. 128), a 'lexical gang'.

To account for the FDG framework of verbs with prefix self-I will profit from an idea launched by Keizer (2016), namely, that of 'partially instantiated frames'. The frames exemplified in (5) are general frames; but the partially instantiated ones inherently contain specific lexical operators or lexical items. For self-prefixed verbs Mackenzie (2018) proposed some partially instantiated frames.

Let's start with (6), the simplest:

(6) $\left(f_{1}:\left[\left(/\right.\right.\right.$ self $\left.\left.\left./ f_{2}: \vee\left(f_{2}\right)\right)\left(x_{1}\right) A\right]\left(f_{1}\right)\right)$

This structure allows the insertion of a verbal lexeme (at position $\$$ ) into a frame that is partially instantiated in containing a so-called 'lexical operator', phonologically specified as /self/. (7) shows an example of such an insertion, namely of the verb isolate, yielding our verb self-isolate:

(7) $\left(f_{i:}\left[\left(/\right.\right.\right.$ self/ $f_{i}:$ / a a səlert $\left.\left.\left./ v\left(f_{i}\right)\right)\left(x_{i}\right)_{A}\right]\left(f_{i}\right)\right)$

In this case, the prefixed verb corresponds to a reflexive conceptualization, as was already mooted by that television presenter.

But in my corpus of the hundred most frequent verbs prefixed with self-, taken from Mark Davies's GloWbE Corpus (DAVIES, 2013), there are also verbs that fit into exactly the same frame but without a sense of reflexivity. These verbs have a meaning associated by König (2011) in his study of self-prefixed nouns, with exclusivity, the idea that someone takes action alone, excluding any help, as in (8):

(8) He decided to self-build when he went in search of a more spacious house.

The most plausible interpretation of this statement is that when he was looking for a bigger home, he decided to build his own house, without help.

There are also verbs in the corpus that the reader can interpret in terms of either reflexivity or exclusivity, for example self-certify in (9):

(9) a. You will be able to self-certify for a week of illness.

b. Some retailers self-certify, which in reality means very little. 
The most plausible interpretation of $(9 a)$ is that you can register your own illness (the reflexive interpretation), while the most plausible interpretation of (9b) is that some retailers certify products without assistance (the exclusive interpretation). But what I want to emphasize is that the frame is not a representation of the meaning but rather a tool used by the speaker (or in this case the writer) to stimulate an interpretation process on the part of the addressee (or in this case, the reader). The choice of a frame is therefore part of the speaker's strategy.

In the corpus there are also several examples of verbs prefixed with self- with two arguments, bivalent verbs, for which I propose the frame in (10):

(10) $\left(f_{1}:\left[\left(/\right.\right.\right.$ self $\left.\left.\left./ f_{2}: \checkmark\left(f_{2}\right)\right)\left(x_{1}\right)_{A}\left(v_{1}\right) u\right]\left(f_{1}\right)\right)$

Consider the examples in (11):

(11) a. Students must self-declare that they wish to graduate.

b. I'm just trying to self-justify drinking Guinness.

The most plausible interpretation of (11a) is that students must themselves personally declare that they wish to be present at the graduation ceremony (the exclusive interpretation), while the most plausible interpretation of (11b) is reflexive, namely that I am trying to justify drinking Guinness (an Irish beer) to myself. This bivalent frame has even a third interpretation, the causative one, exemplified in (12):

(12) He threatened to self-deport Hispanics.

This example alludes to the Republican candidate in the 2012 presidential elections in the USA, who threatened to make the lives of migrants from Latin America so unpleasant that they would voluntarily return to their countries of origin. It is seen very clearly in this example that the attribution of a verb (in this case deport) to this frame triggers a process of interpretation that is sometimes quite complex and depends on various pieces of background information and inferences.

For the sake of completeness, I do not want to neglect a third frame, which corresponds to several examples (which I did not expect to find in the data at the beginning) with not only the prefix self- but also an explicit reflexive pronoun. The frame is shown in (13) and two examples are given in (14):

(13) $\left(f_{1}:\left[\left(/\right.\right.\right.$ self $\left.\left.\left./ f_{2}: \vee\left(f_{2}\right)\right)\left(x_{1}\right)_{A}\left(x_{1}\right) \cup\right]\left(f_{1}\right)\right)$ 
(14) a. He got his name splashed around the media to self-promote himself.

b. No one likes to self-apply categories such as "baby boomer" to themselves.

(14a) means that he had his name distributed through the media in order to promote his own career and (14b) that no one likes to apply categories like "postwar generation" to themselves. So there seems to be a redundancy in self-promote himself or self-apply ... to themselves, and in fact it would be perfectly possible to omit either the prefix or the reflexive pronoun and retain the same interpretation, but not both of course. For me, these types of examples are more proof that the frames do not represent the meaning but are indeed a tool that aims to circumscribe the reader's interpretation process. It is possible that, in this case, the presence of the apparently redundant reflexive pronoun serves to guide this process of interpretation, limiting it to a reflexive interpretation.

I would like to end by returning briefly to the verb self-isolate, a verb that has played such a prominent role in these days of total and partial confinement. For this purpose I will make grateful use of some of the corpora made available by Mark Davies on his website English-Corpora.org (see his contribution to Abralin ao Vivo on May 26th 2020). Of particular interest here is the Coronavirus Corpus (DAVIES, 2020-), https://www.englishcorpora.org/corona/, launched on May 15th 2020, which provides texts from newspapers and magazines published online in English around the world since the beginning of the epidemiological crisis. Each day some 3 to 4 million words are added. We see in Figure 4 (this and all following Figures derive from consultations on March $24^{\text {th }}, 2021$ ) that self-isolate is particularly common in the United Kingdom, Canada, New Zealand, Ireland and Australia, fairly common in Africa but relatively uncommon in Asia and the United States. Part of the explanation may be that in Africa, Asia and the United States the most commonly used verb is self-quarantine, see Figure 5. It is evident that the two verbs are more or less synonymous and are inserted into the same frame, shown as (6) above: the process of lexical insertion in this case appears to depend on what has become entrenched in the particular social environment of the language user. 


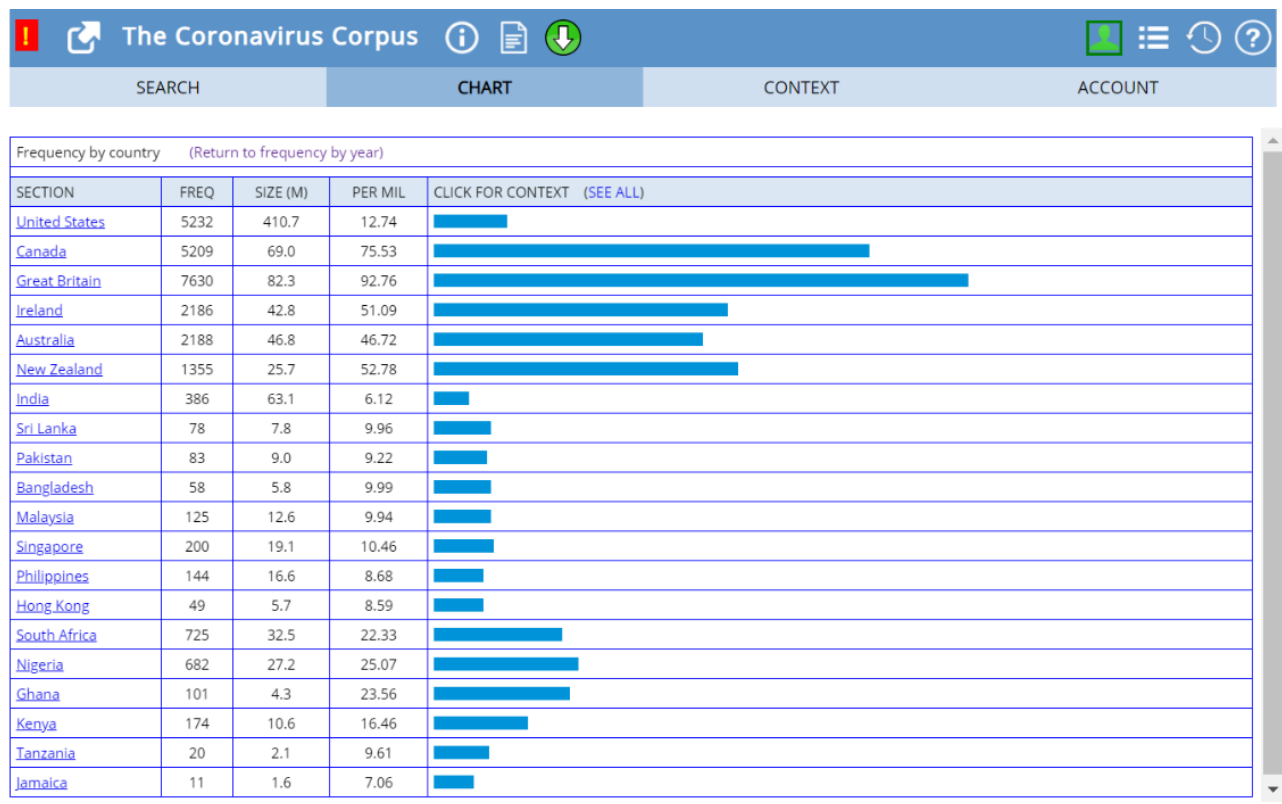

Figure 4. Relative distribution of self-isolate across English-speaking countries.

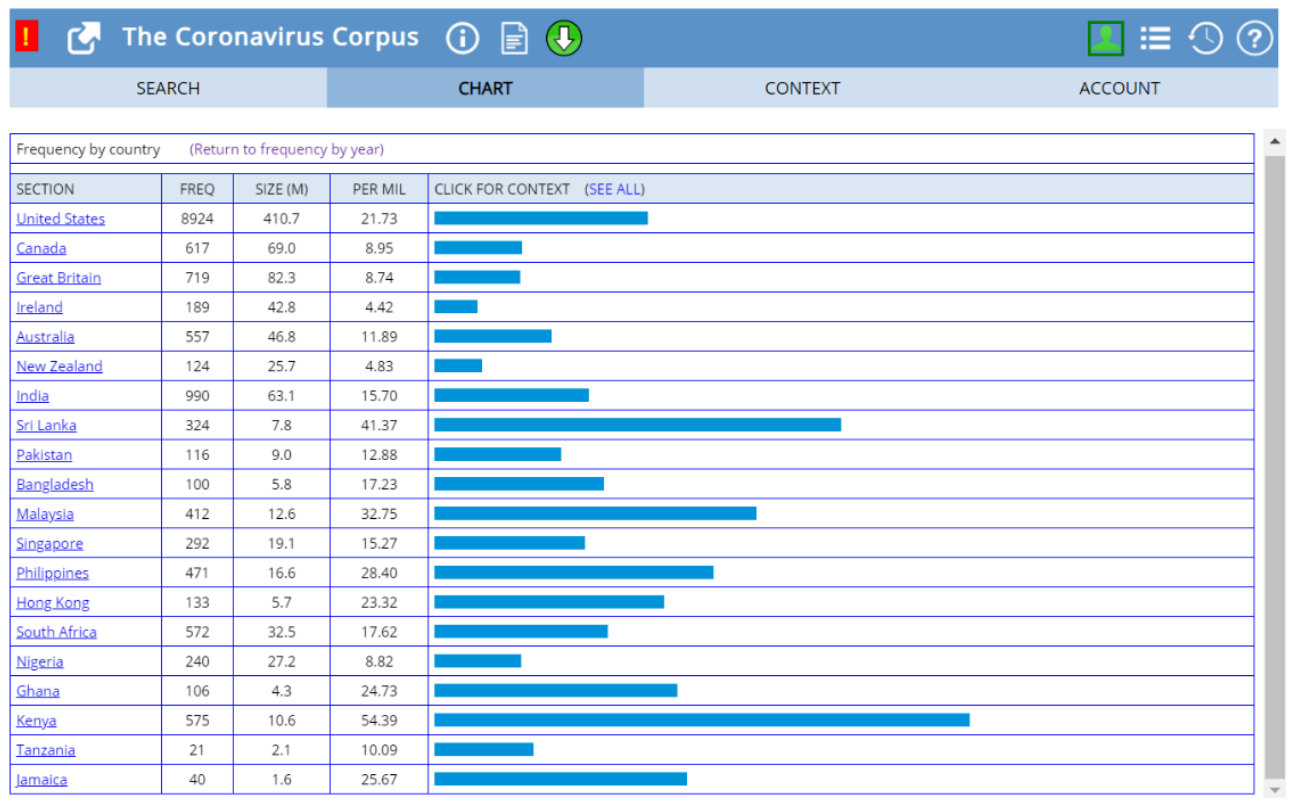

Figure 5. Relative distribution of self-quarantine across English-speaking countries.

At the beginning of the period January 2020 to March 2021, the verb self-isolate was still infrequent (4.90 words per million) but by mid-March it had reached 67.24 words per million before stabilizing at a lower level (see Figure 6); the verb self-quarantine (see Figure 7) initially follows a very similar path, but by December 2020 falls to an even lower level than its initial frequency. 


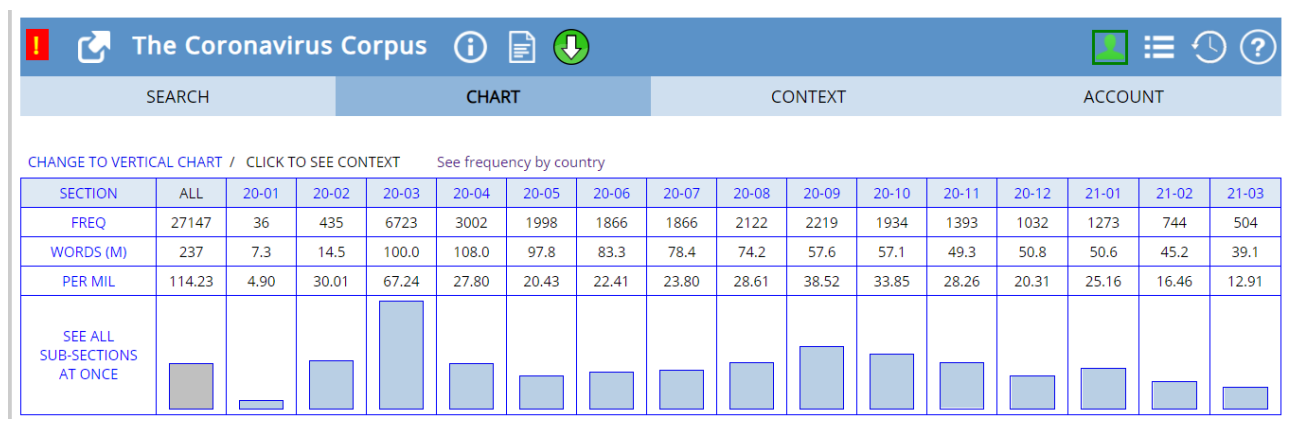

Figure 6. Frequency of self-isolate from 20-01-20 to 21-03-21.

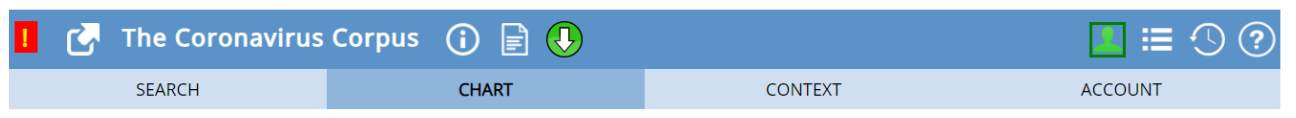

\begin{tabular}{|c|c|c|c|c|c|c|c|c|c|c|c|c|c|c|c|c|}
\hline HANGE TO VER & HAR & CLLR & EE C & & ee frequ & cy by co & & & & & & & & & & \\
\hline SECTION & ALL & $20-01$ & $20-02$ & $20-03$ & $20-04$ & 20-05 & $20-06$ & 20-07 & $20-08$ & $20-09$ & 20-10 & $20-11$ & $20-12$ & $21-01$ & $21-02$ & 21.03 \\
\hline FREQ & 16247 & 66 & 505 & 6300 & 2485 & 1346 & 1011 & 1113 & 685 & 426 & 648 & 649 & 351 & 362 & 169 & 131 \\
\hline WORDS (M) & 237 & 7.3 & 14.5 & 100.0 & 108.0 & 97.8 & 83.3 & 78.4 & 74.2 & 57.6 & 57.1 & 49.3 & 50.8 & 50.6 & 45.2 & 39.1 \\
\hline PER MIL & 68.36 & 8.99 & 34.84 & 63.01 & 23.01 & 13.76 & 12.14 & 14.19 & 9.24 & 7.39 & 11.34 & 13.17 & 6.91 & 7.16 & 3.74 & 3.35 \\
\hline $\begin{array}{c}\text { SEE ALL } \\
\text { SUB-SECTIONS } \\
\text { ATONCE }\end{array}$ & & & & & & & & & & & & & & & & \\
\hline & & $\square$ & & & & & & & 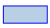 & $\square$ & & & $\square$ & $\square$ & 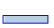 & 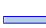 \\
\hline
\end{tabular}

Figure 7. Frequency of self-quarantine from 20-01-20 to 21-03-21.

A look at Mark Davies's ten billion-word NOW Corpus (DAVIES, 2016-) https://www.english-corpora.org/now/, see Figure 8, reveals that the verb self-isolate is really new and in effect was created in 2020, while Figure 9 shows a similar picture for selfquarantine.

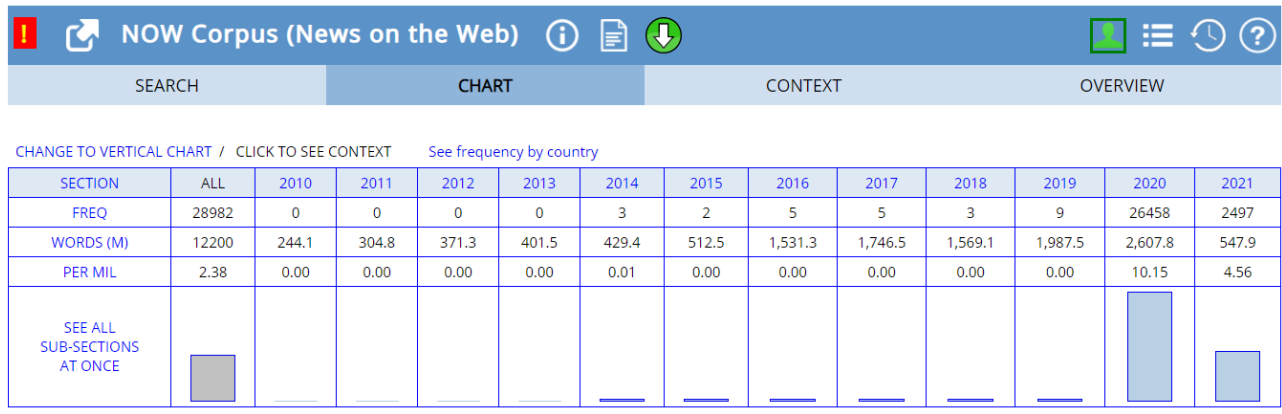

Figure 8. Sudden appearance of self-isolate in 2020 


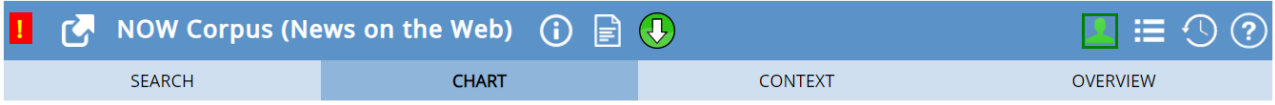

CHANGE TO VERTICAL CHART / CLICK TO SEE CONTEXT
\begin{tabular}{|c|c|c|c|c|c|c|c|c|c|c|c|c|c|}
\hline SECTION & ALL & 2010 & 2011 & 2012 & 2013 & 2014 & 2015 & 2016 & 2017 & 2018 & 2019 & 2020 & 2021 \\
\hline FREQ & 17467 & 0 & 0 & 0 & 1 & 17 & 3 & 0 & 1 & 4 & 4 & 16765 & 672 \\
\hline WORDS (M) & 12200 & 244.1 & 304.8 & 371.3 & 401.5 & 429.4 & 512.5 & $1,531.3$ & $1,746.5$ & $1,569.1$ & $1,987.5$ & $2,607.8$ & 547.9 \\
\hline PER MIL & 1.43 & 0.00 & 0.00 & 0.00 & 0.00 & 0.04 & 0.01 & 0.00 & 0.00 & 0.00 & 0.00 & 6.43 & 1.23 \\
\hline $\begin{array}{c}\text { SEE ALL } \\
\text { SUB-SECTIONS } \\
\text { AT ONCE }\end{array}$ & & & & & & & & & & & & $\square$ & \\
\hline
\end{tabular}

Figure 9. Sudden appearance of self-quarantine in 2020.

And what about the combination with the apparently redundant reflexive pronoun? The NOW Corpus reveals a total of 199 instances of self-isolate in 2020 with reflexive pronoun (and none in the preceding ten years) and 134 instances of self-quarantine with reflexive pronoun (and again none in the preceding ten years). Here are two examples chosen at random:

(15) I had to self-isolate myself for a week and I nearly cracked up.

(16) The asymptomatic contacts would be asked to self-quarantine themselves.

I conclude that the partially instantiated frame shown in (13) has also been co-opted in the coronavirus era, at least by some language users.

For those readers who did not yet know FDG, I trust this article has given a small sample of how (and how well) it works; for those who are already familiar with the framework, I hope to have contributed some valuable new reflections. The most important message is that a language is a tool in social interaction, used strategically by speakers to stimulate processes of inference and interpretation by the addressee. The task of FDG researchers is to study the internal structure of this tool.

\section{REFERENCES}

ALTURO Núria, KEIZER Evelien, PAYRATÓ Lluís, eds. The interaction between context and Grammar in Functional Discourse Grammar. Pragmatics 2014; 24 (2).

CAMACHO Roberto Gomes, PEZATTI Erotilde Goreti, eds. Transparency in indigenous languages of Brazil. Liames 2018; 11 (1).

CHOMSKY Noam. Lectures on government and binding. Foris: Dordrecht; 1981.

DAVIES Mark. Coronavirus Corpus. 3-4 million words added daily. 2020-. 
DAVIES Mark. Corpus of Global Web-Based English. 1.9 billion words from speakers in 20 countries. 2013.

DAVIES Mark. NOW Corpus. 7-8 million words added daily. 2016-.

DIK Simon C. Functional Grammar. North-Holland: Amsterdam; 1978.

DIK Simon C. Studies in Functional Grammar. Academic Press: New York and London; 1980.

DIK Simon C. The theory of Functional Grammar. Part 1. Foris: Dordrecht; 1989.

DIK Simon C. Functional Grammar in Prolog: An integrated implementation for English, French and Dutch. Mouton de Gruyter: Berlin; 1992.

DIK Simon C. The theory of Functional Grammar. (Ed. by Kees Hengeveld.) 2 Parts. Mouton de Gruyter: Berlin; 1997.

FILLMORE Charles. The case for case. In BACH Emmon, HARMS Robert T. Universals in linguistic theory. Holt, Rinehart and Winston: New York; 1968: 1-88.

GARCÍA VELASCO Daniel. Lexical competence and Functional Discourse Grammar. Alfa - Revista de Lingüística 2007; 51 (2): 165-187.

GARCÍA VELASCO Daniel. A flexible lexicon for Functional Discourse Grammar. Linguistics 2016; 54 (5): 907-945. DOI: 10.1515/ling-2016-0020

GARCÍA VELASCO Daniel, CONTRERAS GARCÍA Lucía, eds. Interfaces in Functional Discourse Grammar. De Gruyter Mouton: Berlin and New York; 2022 (in preparation).

GARCÍA VELASCO Daniel, RIJKHOFF Jan, eds. The Noun Phrase in Functional Discourse Grammar. Mouton de Gruyter: Berlin and New York; 2008.

GARCÍA VELASCO Daniel, WANDERS Gerry, eds. The Morphosyntactic Level in Functional Discourse Grammar. Language Sciences 2012; 34 (4).

GENEE Inge, KEIZER Evelien, eds. The lexicon in Functional Discourse Grammar. Linguistics 2016; 54 (5).

GIOMI Riccardo. The place of interpersonal lexemes in linguistic theory, with special reference to Functional Discourse Grammar. Corpus Pragmatics 2021; DOI: 10.1007/s41701-020-00094-w

GROOT Casper de, HENGEVELD Kees, eds. Morphosyntactic expression in Functional Grammar. Mouton de Gruyter: Berlin and New York; 2005.

GUERRERO MEDINA Pilar, PORTERO MUÑOZ Carmen, eds. Derivational morphology in Functional Discourse Grammar. Word Structure 2018; 11 (1).

HANNAY Mike, KROON Caroline. Acts and the relationship between discourse and grammar. Functions of Language 2005; 12 (1): 87-124. DOI: 10.1075/fol.12.1.05han

HASPELMATH Martin, SIMS Andrea D. Understanding morphology. $2^{\text {nd }}$ edition. Hodder: London; 2010.

HATTNHER Marize, HENGEVELD Kees, eds. Advances in Functional Discourse Grammar. Alfa - Revista de Lingüística 2007; 51 (2).

HENGEVELD Kees. The architecture of a Functional Discourse Grammar. In MACKENZIE J. Lachlan, GÓMEZ GONZÁLEZ María A. A new architecture for Functional Grammar. Mouton de Gruyter: Berlin; 2004: 1-21.

HENGEVELD Kees, ed. Transparency in Functional Discourse Grammar. Linguistics in Amsterdam 2011; 4.

HENGEVELD Kees, MACKENZIE J. Lachlan. Functional Discourse Grammar: A typologically-based theory of language structure. Oxford University Press: Oxford; 2008.

HENGEVELD Kees, MACKENZIE J. Lachlan. Reflections on the lexicon in Functional Discourse Grammar. Linguistics 2016; 54 (5): 1135-1161. 
HENGEVELD Kees, NARROG Heiko, OLBERTZ Hella, eds. The grammaticalization of tense, aspect, modality, and evidentiality: A functional perspective. Mouton de Gruyter: Berlin; 2017.

HENGEVELD Kees, OLBERTZ Hella, eds. Systems of tense, aspect, modality, evidentiality and polarity in Functional Discourse Grammar. Open Linguistics 2018; 4.

HENGEVELD Kees, WANDERS Gerry, eds. The Representational Level in Functional Discourse Grammar. Lingua 2009; 119 (8).

KEIZER Evelien. A Functional Discourse Grammar for English. Oxford University Press: Oxford; 2015.

KEIZER Evelien. Idiomatic expressions in Functional Discourse Grammar. Linguistics 2016; 54 (5): 981-1016. DOI: 10.1515/ling-2016-0022

KEIZER Evelien, OLBERTZ Hella, eds. Recent developments in Functional Discourse Grammar. John Benjamins: Amsterdam and Philadelphia; 2018.

KÖNIG Ekkehard. Reflexive nominal compounds. Studies in Language 2011; 35 (1): 112-127. DOI: 10.1075/sl.35.1.04koe

KONOPKA Agnieszka E., BROWN-SCHMIDT Sarah. Message encoding. In GOLDRICK Matthew, FERREIRA Victor, MIOZZO Michele. Oxford handbook of language production. Oxford University Press: Oxford; 2014: 3-20.

MACKENZIE J. Lachlan. A first history of Functional Grammar. In ASSUNÇ̃̃O Carlos, FERNANDES Gonçalo, KEMMLER, Rolf. History of Linguistics 2014: Selected Papers from the 13th International Conference on the History of the Lanquage Sciences (ICHoLS XIII), Vila Real, Portugal, 25-29 August 2014. John Benjamins: Amsterdam; 2016: 233-246. DOI: $10.1075 /$ sihols.126.18mac

MACKENZIE J. Lachlan. Self-prefixed verbs: Analogy in the Functional Discourse Grammar lexicon. Word Structure 2018; 11 (1): 67-94. DOI: 10.3366/word.2018.0116

MACKENZIE J. Lachlan, GÓMEZ-GONZÁLEZ María de los Ángeles, eds. A new architecture for Functional Grammar Mouton de Gruyter: Berlin and New York; 2004.

MACKENZIE J. Lachlan, GÓMEZ-GONZÁLEZ María de los Ángeles, eds. Studies in Functional Discourse Grammar. Peter Lang: Berne etc.; 2005.

MACKENZIE J. Lachlan, OLBERTZ Hella, eds. Casebook in Functional Discourse Grammar. John Benjamins: Amsterdam; 2013.

PERLMUTTER David M., POSTAL Paul M. Some proposed laws of basic clause structure. In PERLMUTTER David. Studies in Relational Grammar, Vol. 1. Chicago University Press: Chicago; 1983: 81-128.

PÉREZ QUINTERO María Jesús, ed. Functional Discourse Grammar: Advances and prospects. Revista Canaria de Estudios Ingleses 2013; 67.

VAN STADEN Miriam, KEIZER Evelien, eds. Interpersonal grammar: A crosslinguistic perspective. Linguistics 2009; 47 (4).

WANDERS Gerry, KEIZER Evelien, eds. Special Issue: The London Papers 1. Web Papers in Functional Discourse Grammar 82. 2009.

WANDERS Gerry, KEIZER Evelien, eds. Special Issue: The London Papers 2. Web Papers in Functional Discourse Grammar 83. 2010. 